AKRUAL 5 (2) (2014): 115-132 $e$-ISSN: 2502-6380

\title{
AKRUAL
}

Jurnal Akuntansi

http://fe.unesa.ac.id/ojs/index.php/akrl

\section{PENGARUH GOOD CORPORATE GOVERNANCE (GCG) DAN CORPORATE SOCIAL RESPONSIBILITY (CSR) TERHADAP NILAI PERUSAHAAN DENGAN KINERJA KEUANGAN SEBAGAI VARIABLE INTERVENING PADA PERUSAHAAN PERTAMBANGAN YANG GO PUBLIC DI BEI}

\author{
Suklimah Ratih \\ Yulia Setyarini \\ Fakultas Ekonomi Universitas Widya Kartika Surabaya \\ Email: ratihratih177@ymail.com \\ Artikel diterima: 13 Januari 2014 \\ Terakhir direvisi: 25 Februari 2014
}

\begin{abstract}
Application of Good Corporate Governance (GCG) and Corporate Social Responsibility (CSR) being demands for companles that have involved external parties in fullfilment of the operational funding and have social impact. The effective GCG and CSR will be able to increase the finance performance and value of the firms.This study aimed to determine the direct and indirect effect of GCG dan CSR against the value of the mining companies that go public in BEI, based on sample annual reports 2012. The result of this study is only the KPI (one element of GCG mechanism) that have dirrect effect to fFnancial Performance (ROA), and none of indirect effect hypothesis of GCG and CSR to Value of the Firm (Tobin's Q) are proven.
\end{abstract}

Keywords: Good Corporate Governance $(G C G)$, Corporate Social Responsibility (CSR), Financial Performance, Value of the Firms.

\section{PENDAHULUAN}

Latar Belakang

Good Corporate Governance (GCG) dan Corporate Social Responsibility (CSR) di Indonesia telah diwajibkan untuk perusahaan yang telah melibatkan pihak eksternal dalam pemenuhan pendanaannya dan yang berdampak sosial operasinya. Di Indonesia penerapan GCG diatur dalam Peraturan Bapepam Nomor VIII.G.2, 2002 kewajiban pengungkapan CSR telah diatur dalam UURI. No. 40 tahun 2007.

GCG maupun CSR kemungkinan akan berdampak terhadap kinerja perusahaan dan juga terhadap nilai perusahaan. Penerapan GCG dan CSR yang efektif akan meningkatkan kinerja keuangan maupun kinerja pasar atau memaksimalkan nilai perusahaan. Penelitian ini ditujukan untuk mengetahui 
pengerug GCG dan CSR terhadap nilai perusahaan dengan kinerja keuangan sebagai variabel intervening.

Sebagai suatu tanggung jawab, baik GCG maupun CSR sangat menarik untuk dikaji penerapannya pada perusahaan yang bergerak pada bidang pertambangan yang umumnya sangat banyak membutuhkan pendanaan karena padat modal. Di sisi lain sebagai perusahaan yang eksploratif maka sangat erat pula kaitannya dengan kewajiban melaksanakan kegiatan CSR dan mengungkapkannya pada laporan tahunan perusahaan .

Penelitian ini bermanfaat untuk memberikan tambahan wawasan bagi stakeholder sehingga bisa memanfaatkan informasi yang lebih komprehensif dari perusahaan bidang pertambangan, yang dapat dianalisis dari laporan tahunan. Dalam penelitian ini GCG dipandang dari mekanismenya menggunakan proksi Independensi Dewan Komisaris (IDK), dan Kepemilikan Institusional (KPI) sedangkan CSR diproksi dengan pengungkapan CSR. Kinerja Keuangan perusahaan dalam penelitian ini adalah ROA, sedangkan nilai perusahaan di-proksi dengan nilai pasar perusahaan yang diukur dengan Tobin's $Q$. Data-data penelitian diambil dari laporan tahunan perusahaan-perusahaan tersebut pada tahun 2012.

\section{Rumusan Masalah}

Berdasar latar belakang tersebut rumusan masalah yang dapat dibuat adalah : Bagaimanakah pengaruh GCG yang diproksi Independensi Dewan Komisaris, (IDK), Kepemilikan Institusional (KPI) dan CSR terhadap Nilai Perusahaan dengan Kinerja Keuangan ROA sebagai variabel intervening?

\section{Tujuan Penelitian}

Sesuai dengan rumusan masalah dalam penelitian ini, maka tujuan penelitan adalah untuk mengetahui pengaruh GCG yang diproksi Independensi Dewan Komisaris, (IDK), Kepemilikan Institusional (KPI) dan CSR terhadap Nilai Perusahaan dengan Kinerja Keuangan ROA sebagai variabel intervening.

\section{KAJIAN PUSTAKA}

Terdapat tiga grand theories yang menurut peneliti terkait erat dengan penelitian ini yaitu: 1) stewardship theory, 2) agency theory dan 3) signalling theory yang masing-masing dapat dijabarkan sebagai berikut:

\section{Stewardship theory}

"Stewardship theory dibangun di atas asumsi filosofis mengenai sifat manusia yakni bahwa manusia pada hakekatnya dapatdipercaya, memandang manajemen sebagai dapat dipercaya untuk bertindak dengan sebaik-baiknya bagi kepentingan publicmaupun stakeholder" (Kaihatu, 2006). Laporan tahunan sebagai alat pertanggungjawaban manajemen. 


\section{Agency Theory (Teori Keagenan)}

Jensen dan Meckling(1976) menyebutkan teori keagenan sebagai " an agency relationship" dan menjelaskannya sebagai berikut : "an agency relationship as a contract under which one or more person(the prinsipal(s)) engage another person (the agent) to perform some services on their behalf wich involves delegating some decision making authority to the agent. Teori ini mengakui adanya konflik kepentingan pada pihak manajemen dan pemilik, dimana memunculkan asimetri informasi.

\section{Signalling Theory}

Vernimmen (2009) menyatakan sebagai berikut: "Signalling theory states that corporate financial decisions are signals sent by the company's managers to investors in order to shake up these asymmetries. Disinilah letak pentingnya para stakeholder terutama kreditor dan investor bisa memanfaatkan informasi baik yang bersifat keuangan ataupun non keuangan untuk mengambil keputusan bisnisnya dan melemahkan asimetri informasi. Salah satunya juga menganalisis penerapan GCG dan CSR perusahaan".

\section{Good Corporate Governance (GCG)}

\section{Pengertian GCG}

Menurut Forum for Corporate Governance Indonesia (FCGI, 2006) Corporate Governance didefinisikan sebagai seperangkat peraturan hubungan antara pemegang saham, pengelola perusahaan, pihak kreditur, pemerintah, karyawan serta para pemegang kepentingan intern dan ekstern lainnya.

Dari latar belakang akademis, kebutuhan good corporate governance timbul berkaitan dengan principal-agency theory, yaitu untuk menghindari konflik antara principal dan agentnya. Selanjutnya FCGI menyatakan" The objective of corporate governance is to create added value to the stakeholder"

\section{Mekanisme GCG}

Menurut Iskandar \& Chamlou (2000) mekanisme corporate governance dibagi menjadi dua kelompok. Pertama berupa internal mechanism (mekanisme internal). seperti rapat umum pemegang saham, komposisi dewan komisaris, komposisi dewan direksi, sekretaris perusahaan, struktur kepemilikan dan pertemuan dengan board ofdirectors, sedangkan Struktur kepemilikan perusahaan dibedakan menjadi: Tingkat konsentrasi kepemilikan dan Kepemilikan Perusahaan.

Kedua, Exsternal mechanism adalah cara mempengaruhi perusahaan selain dengan menggunakan mekanisme eksternal perusahaan melalui komisaris independen. Ketentuan Bursa Efek, jumlah komisaris independen sekurangkurangnya $30 \%$. 


\section{Corporate Social Responsibility (CSR)}

CSR merupakan komitmen perusahaan untuk bertanggung jawabnya kepada lingkungan dan masyarakat sekitar yang terkena dampak kurang baik atas praktek bisnis perusahaan, berupa melimpahnya polutan yang harus ditanggung masyarakat sekitar. . (UU. No. 40 Th. 2007 ). FCGI, (2006) menyebutkan ada tiga tipe CSR yaitu charity, pembinaan mitra secara parsial dan peningkatan perekonomian masyarakat yang berefek peningkatan produktivitas dan efisiensi perusahaan.

Berdasar penelitian yang dilakukan oleh Sembiring (2005), kategori pengungkapan tanggung jawab sosial 1) Lingkungan, 2) Energi, 3) Kesehatan dan Keselamatan Tenaga Kerja, 4) Lain-lain tentang Tenaga Kerja, 5) Produk, 6) Keterlibatan Masyarakat dan 7) Umum. Total pengungkapan CSR sebanyak 78 item.

\section{Kinerja Keuangan Perusahaan}

Kinerja perusahaan adalah istilah untuk menunjukkan keberhasilan perusahaan dalam menjalankan usahanya. Rasio pengukur kinerja keuangan perusahaan sebenarnya sangat banyak, dalam penelitian ini peneliti mengambil salah satu rasio profitabilitas sebagai proksi kinerja keuangan perusahaan, yaitu ROA (Return on Assets). Menurut Bodie et.al (2009:636) “...ROA, which measures profitability for all contributors of capital, is defined as earning before interest and taxes (EBIT), divided by total assets".

\section{Nilai Perusahaan (NP)}

Teori yang dikemukakan oleh Modigliani dan Miller menyatakan bahwa nilai perusahaan ditentukan oleh earnings power dari aset perusahaan. Nilai perusahaan(Market Value of The firm) terdiri dari nilai hutang dan nilai saham dibanding nilai asset. Salah satu rasio yang bisa digunakan adalah Tobin' $Q$ seperti yang dilakukan oleh beberapa peneliti sebelumnya yaitu (Black,2008) dan (Pranata,2007),

Tobin'Q ratio mengukur : "...if $Q$ (represent equilibrium) is greater than one $(Q>1)$, additional investment in the firm would make sense because the profit generated would exceed the cost of the firm's assets. If $q$ less than one $(Q<1)$, the firm would better off selling its

\section{Penelitian Sebelumnya}

Penelitian sebelumnya yang digunakan ada empat: Penelitian pertama dengan variabel GCG sebagai variabel bebas dan Nilai Perusahaan sebagai variabel terikat adalah penelitian dari peneliti sendiri, Ratih (2011) dengan variabel GCG yang diproksi dengan Corporate Governance Perception Index (CGPI) sebagai variabel bebas dan nilai perusahaan dengan proksi Tobin's Q sebagai variabel terikat Tobin's $Q$ dengan CSR, ROA dan EM sebagai variabel intervening menunjukkan hanya variabel ROA yang secara positif dan signifikan terhadap Nilai Perusahaan (Tobin"s 
Q) dan hanya ROA yang terbukti bisa menjadi variabel intervening. Persamaan penelitian ini dengan penelitian Ratih yang sebelumnya adalah sama-sama menggunakan variabel GCG dan Nilai Perusahaan, sedangan perbedaannya adalah proksi GCG, jumlah variabel intervening dan obyek serta tahun penelitian. Penelitian pertama dengan variabel GCG sebagai variabel bebas dan nilai perusahaan sebagai variabel terikat adalah penelitian Black. et.al.(2008), yang menunjukkan hasil Corporate Governance berpengaruh terhadap nilai perusahaan yang diukur dengan Tobin's $Q$. Persamaannya dengan penelitian Black adalah sama-sama menggunakan GCG dan menguji pengaruhnya terhadap nilai perusahaan. Perbedaannya penelitian Black menggunakan GCG index tidak memasukkan variabel CSR serta pengaruhnya terhadap kinerja keuangan, tetapi melakukan pengujian lebih lanjut pada berbagai possible channels, serta beda tempat (negara).

Penelitian sebelumnya yang kedua dilakukan oleh Huang (2010), menguji pengaruh GCG terhadap kinerja perusahaan yaitu kinerja keuangan yang diproksi dengan ROA dan terhadap kinerja CSR yang diukur dengan kinerja sosial. Penelitian ini menunjukkan hasil: GCG (Independensi Dewan Komisaris) memiliki pengaruh positif signifikan terhadap kinerja keuangan (ROA), sedangkan Kepemilikan Institusional tidak berpengaruh terhadap ROA. Persamaannya yaitu menguji pengaruh GCG yang diukur dengan mekanisme GCG terhadap kinerja keuangan. Perbedaannya adalah penelitian Huang tidak menggunakan kinerja keuangan sebagai variabel intervening.

Penelitian sebelumnya ketiga tentang GCG yang dilakukan Pranata (2007), menguj pengaruh Penerapan Good Corporate Governance terhadap Kinerja Keuangan Perusahaan (ROE, NPM dan Tobin's $Q$ ) diperoleh hasil bahwa GCG berpengaruh positif terhadap semua variable kinerja keuangan perusahaan. peraih 10 besar CGPI. Persamaannya adalah sama - sama menguji pengaruh GCG terhadap kinerja keuangan. Perbedaannya adalah pada penelitian Pranata tidak menguji pengaruh CSR terhadap nilai perusahaan, dan memasukkan nilai pasar perusahaan dengan pengukuran Tobin's Q sebagai salah satu proksi dari kinerja keuangan, sedangkan penulis memasukkan sebagai proksi dari nilai perusahaan.

Penelitian keempat dengan variabel GCG sebagai variabel bebas dan nilai perusahaan sebagai variabel terikat adalah penelitian Black. et.al.(2008), yang menunjukkan hasil Corporate Governance berpengaruh terhadap nilai perusahaan yang diukur dengan Tobin's $Q$. Persamaannya dengan penelitian Black adalah menggunakan GCG dan menguji pengaruhnya terhadap nilai perusahaan. Perbedaannya penelitian Black menggunakan GCG index tidak memasukkan variabel CSR serta pengaruhnya terhadap kinerja keuangan, tetapi melakukan pengujian lebih lanjut pada berbagai possible channels, serta beda tempat (negara).

Penelitian sebelumnya yang keempat dengan variabel GCG sebagai variabel bebas dan nilai perusahaan sebagai variabel terikat adalah penelitian Black. et.al.(2008), yang menunjukkan hasil Corporate Governance berpengaruh terhadap nilai perusahaan yang diukur dengan Tobin's $Q$. Persamaannya dengan penelitian Black adalah menggunakan GCG dan menguji pengaruhnya terhadap nilai perusahaan. 
Perbedaannya penelitian Black menggunakan GCG index tidak memasukkan variabel CSR serta pengaruhnya terhadap kinerja keuangan, tetapi melakukan pengujian lebih lanjut pada berbagai possible channels, serta beda tempat (negara).

\section{PENGEMBANGAN HIPOTESIS}

Berdasarkan latar belakang masalah dan rumusan masalah, maka dapat dirumuskan hipotesis sebagai berikut:

$\mathrm{H}_{1}$ : IDK berpengaruh langsung terhadap ROA

$\mathrm{H}_{2}$ : KPI berpengaruh langsung terhadap ROA

$\mathrm{H}_{3}$ : CSR berpengaruh langsung terhadap ROA

$\mathrm{H}_{4}$ : ROA berpengaruh langsung terhadap Tobin's Q

$\mathrm{H}_{5}$ : IDK berpengaruh tidak langsung terhadap Tobin's Q dengan variabel intervening ROA

$\mathrm{H}_{6}$ : KPI berpengaruh tidak langsung terhadap Tobin's $\mathrm{Q}$ dengan variabel intervening ROA

$\mathrm{H}_{7}$ :CSR berpengaruh tidak langsung terhadap Tobin's $\mathrm{Q}$ dengan variabel intervening ROA

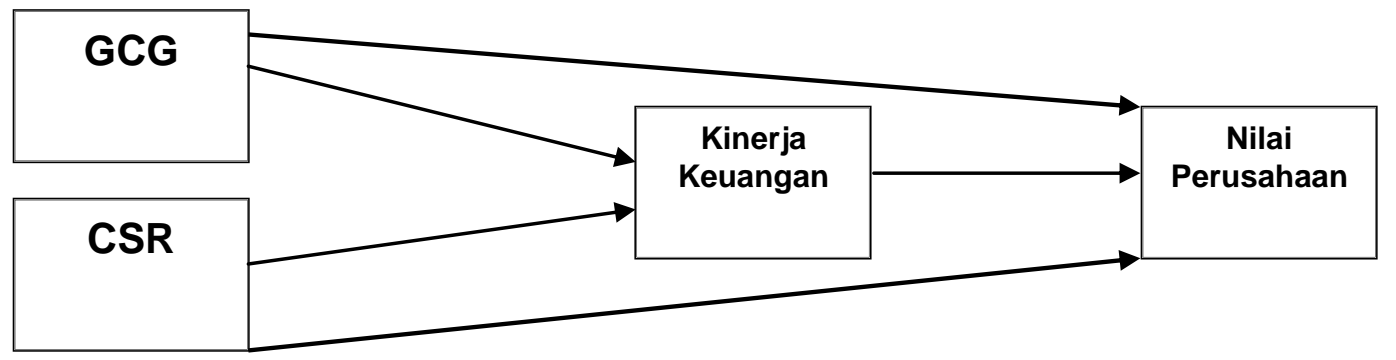

Gambar 1. Rerangka Konseptual Penelitian 


\section{METODE PENELITIAN}

\section{Pendekatan Penelitian}

Penelitian ini menggunakan pendekatan kuantitatif yaitu yang melakukan pengujian terhadap hubungan kausal atau pengaruh dari variabel-variabel penelitian yang terukur terhadap variabel lain yang terukur pula.

\section{Objek Penelitian}

Obyek dari penelitian ini adalah perusahaan-perusahaan pertambangan yang telah go public di BEI tahun 2012 sebanyak 31 perusahaan. Media yang dipergunakan untuk memperoleh data penelitian dari obyek penelitian tersebut adalah: 1) Laporan tahunan perusahaan - perusahaan pertambangan yang TBK. (go public) di BEI pada tahun 2012 untuk mendapatkan data pengukuran variabelvariabel GCG yang diproksi dengan Mekanisme GCG.

\section{Populasi, Sampel dan Pengambilan Sampel}

Dalam penelitian ini semua populasi dijadikan sampel penelitian yaitu semua perusahaan bidang pertambangan yang telah go public tahun 2012.

\section{Prosedur Pengumpulan Data dan Analisis Data}

Teknik pengumpulan data yang penulis lakukan dalam penelitian menggunakan cara dokumentasi, sedangkan untuk analisis data dalam penelitian ini menggunakan Model Analisis Jalur dengan menggunakan program Software SPSS for Windows release 15.0.

Langkah-langkah dalam analisis jalur adalah (Hair, 2010) disesuaikan dengan penelitian ini adalah sebagai berikut:

1. Menstandarkan semua data penelitian dimana semua variabel penelitian ini terukur.

2. Menggambarkan rancangan diagram jalur sebagaimana yang dijabarkan di atas.

3. Menganalisis persamaan analisis jalur dan pengujian hipotesis dengan program Software SPSS for Windows release 15.0 di atas.

4. Menganalisis dan mengiterpretasikan hasil dari pengolahan data tersebut di atas, sebagai berikut:

a. Pengaruh langsung

Pengujian pengaruh langsung yang dilakukan dengan Uji Partial ( Uji t ) untuk mengetahui pengaruh tiap - tiap variabel $\mathrm{X}$ terhadap variabel $\mathrm{Y}$ secara partial.

b. Pengaruh tidak langsung

Untuk mengetahui adanya hubungan tidak langsung dengan melakukan perkalian terhadap koefisien jalur pertama dengan koefisien jalur selanjutnya. Apabila hasil perkalian tersebut hasilnya lebih besar dari koefisien hubungan langsungnya maka berarti variabelY1 tersebut adalah variable intervening, 


\section{Definisi Operasional Variabel}

Penelitian ini melibatkan lima variabel dengan klasifikasi sebagai berikut:

1. Variabel bebas (independent variable) yaitu Good Corporate Governance dan Corporate Social Responsibility

GCG adalah sebuah sistem yang mengawasi dan mengendalikan perusahaan, yang bertujuan untuk mencapai efisiensi penggunaan dana serta pengawasan penggunaannya.

Variabel GCG ini menggunakan mekanisme GCG dengan proksi dua variabel yaitu:

a. Independensi Dewan Komisaris (X1), adalah organ tambahan perusahaan yang mewakili pemilik. Independensi dewan komisaris ditunjukkan dengan prosentase komisaris independen yang ada dalam dewan komisaris.

Independensi Dewan Komisaris $=$ Jumlah anggota dewan komisaris independen

$$
\text { Jumlah total anggota dewan komisaris }
$$

b. Kepemilikan Institusional (X2), yaitu tingkat kepemilikan Institusional (Institutional Ownership) diukur dengan prosentase saham yang dimiliki institusi dibagi dengan jumlah saham yang beredar.

Kepemilikan Institusional $\quad=\%$ saham yang dimiliki institusi

Jumlah saham beredar

Corporate Social Responsibility (X3), adalah suatu bentuk kepedulian dan tanggungjawab perusahaan terhadap lingkungan dan masyarakat sekitanya yang terkait dan terkena dampak dari operasi perusahaan yang diukur dengan prosetase pengungkapan CSR perusahaan, mengacu pada hasil penelitian Sembiring (2005).

$\mathrm{CSR}=\%$ pengungkapan $\mathrm{CSR}$ perusahaan

2. Variabel terikat (dependent variable), yaitu ROA (Y1) dan Nilai Perusahaan (Y2). Return on Assets (ROA) adalah rasio kinerja keuangan pada sisi profitabilitas yang menunjukkan kemampuan perusahaan memanfaatkan asetnya untuk menciptakan laba tanpa membedakan dari mana sumber pendanaannya.

ROA $=$ EBIT $:$ Total Aset $($ BVTA, Book Value of Total Assets $)$

Nilai Pasar Perusahaan (NPP) merupakan rasio yang menunjukkan bagaimana nilai pasar perusahaan apabila dibandingkan dengan nilai bukunya. Rasio yang digunakan untuk mengukurnya adalah Tobin's $Q$. 
Tobin's Q = ( MVCS + BVD ) / BVTA, dimana

EMV : Equity Market Value (Closing Price

BVD : Book Value of Debt

BVTA : Book Value of Total Assets

\section{Model Analisis}

Penelitian ini menggunakan model analisis jalur (Path Analysis) yang dikembangkan oleh Sewall Wright (1934) yang disebutkan dalam Denis (2003), karena tujuan penelitian ini adalah menerangkan akibat langsung dan tidak langsung seperangkat variabel terukur (parametrik) dengan satu variabel intervening.

\section{Analisis Regresi Linear untuk Pengaruh Langsung}

Model analisis jalur menggunakan analisis statistik regresi linear, menurut Mulyono $(2003,236)$ untuk menguji pengaruh langsung sebagai berikut:

1. Pengaruh IDK terhadap ROA yaitu e1

2. Pengaruh KPI terhadap ROA yaitu e2

3. Pengaruh CSR terhadap ROA yaitu e3

4. Pengaruh ROA terhadap Tobin's Q yaitu e4

5. Pengaruh IDK terhadap Tobin's Q yaitu e5

6. Pengaruh KPI terhadap Tobin's Q yaitu e6

7. Pengaruh CSR terhadap Tobin's Q yaitu e7

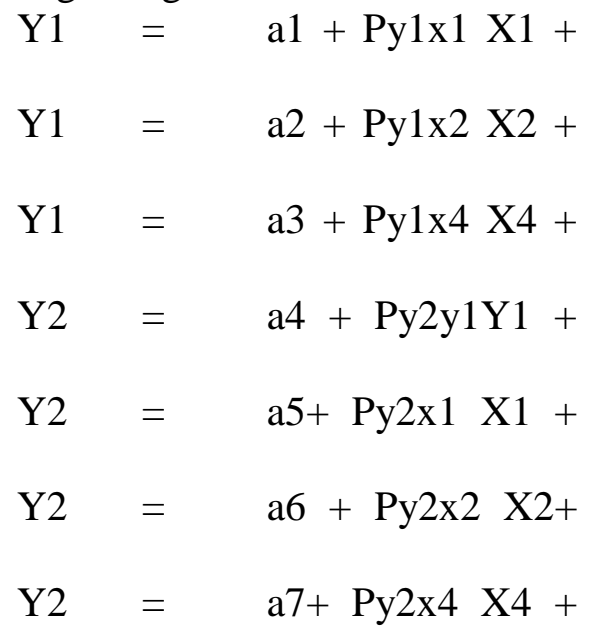

$\mathrm{Y} 2=\mathrm{a} 7+\mathrm{Py} 2 \mathrm{x} 4 \mathrm{X} 4+$

Hubungan kausal antara satu variabel $\mathrm{X}$ terhadap satu variabel $\mathrm{Y}$ dengan diwakili pengaruh X1 terhadap Y1 dapat digambarkan sebagai berikut:

Py1x1 X1

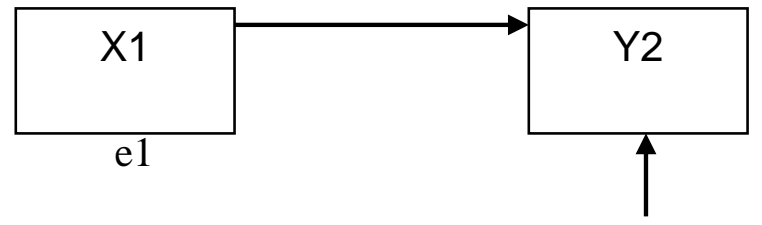

Gambar 2. Hubungan Kausal antara Variabel Bebas X1 terhadap Variabel

Terikat Y1 dengan Variabel Residu e1

Sumber : Model Regresi, digambarkan Peneliti 


\section{Mengidentifikasikan Substruktur Path Analysis}

1. Hubungan kausal tidak langsung dikatakan terjadi apabila perkalian antara koefisien hubungan langsung variabel X dengan Y1 dengan koefisien Y1 terhadap $\mathrm{Y} 2$ lebih besar dibandingkan dengan koefisien hubungan langsung variabel $\mathrm{X}$ terhadap variabel Y2 yang dapat digambarkan sebagai berikut

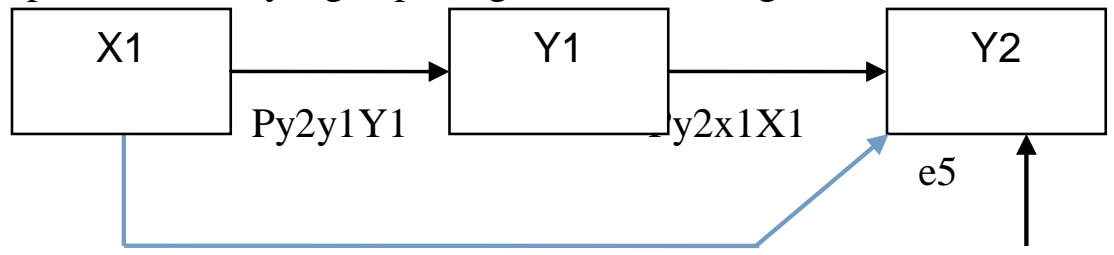

Gambar 3. Hubungan Kausal antara Variabel Bebas X1 terhadap Variabel
Terikat Y2 dengan Intervening Y1 dan Variabel Residu e5
Sumber : Model Path Analysis, digambarkan Peneliti.

Apabila $(\mathrm{Py} 1 \mathrm{x} 1 \mathrm{X} 1)(\mathrm{Py} 2 \mathrm{y} 1 \mathrm{Y} 1)>\mathrm{Py} 2 \mathrm{x} 1 \mathrm{X} 1$ maka $\mathrm{Y} 1$ adalah variabel intervening

Tabel 1. Variabel-Variabel Penelitian dan Pengukurannya

\begin{tabular}{|c|c|c|c|c|c|c|c|}
\hline No. & NAMA PERUSAHAAN & KODE & $\begin{array}{l}\text { IDK } \\
\text { (X1) }\end{array}$ & $\begin{array}{l}\text { KPI } \\
\text { (X2) }\end{array}$ & $\begin{array}{l}\text { CSR } \\
\text { (X3) }\end{array}$ & $\begin{array}{l}\text { R)A } \\
\text { (Y1) }\end{array}$ & $\begin{array}{l}\text { TOBIN'SQ } \\
\text { (Y2) }\end{array}$ \\
\hline 01. & Attlas Resources Tbk & ARI & 0,33 & 0,51 & 0,28 & $-0,05$ & 2,37 \\
\hline 02. & Adaro Energy Tbk. & ADRO & 0,33 & 0,44 & 0,4 & 0,13 & 1,31 \\
\hline 03. & ATPK Resources Tbk. & ATPK & 0,33 & 0,73 & 0,05 & $-0,09$ & 1,71 \\
\hline 04. & $\begin{array}{l}\text { Aneka Tambang (Pesero) } \\
\text { Tbk. }\end{array}$ & ANTM & 0,17 & 0,77 & 0,45 & 0,2 & 3,67 \\
\hline 05. & Bayan Resources Tbk & BYAN & 0,4 & 0,3 & 0,24 & 0,08 & 3,19 \\
\hline 06. & Berau Coal Energy Tbk & BRAU & 0,4 & 0,88 & 0,29 & $-0,16$ & 1,2 \\
\hline 07. & $\begin{array}{l}\text { Borneo Lumbung Energy } \\
\& \text { Metal Tbk. }\end{array}$ & BORN & 0,6 & 0,65 & 0,22 & $-0,21$ & 2,6 \\
\hline 08. & Bukit Asam Tbk. & PTBA & 0,33 & 0,75 & 0,37 & 0,31 & 3,07 \\
\hline 09. & Bumi Resources Tbk. & BUMI & 0,67 & 0,29 & 0,26 & 0,1 & 1,03 \\
\hline 10. & $\begin{array}{l}\text { Benakat Petroleum Energy } \\
\text { Tbk. }\end{array}$ & BIPI & 0,4 & 0,42 & 0,23 & 0,04 & 3,39 \\
\hline 11. & $\begin{array}{l}\text { Central Omega Resources } \\
\text { Tbk. }\end{array}$ & DKFT & 0,17 & 0,75 & 0,22 & 0,29 & 1,51 \\
\hline 12. & $\begin{array}{l}\text { Cita Mineral Investindo, } \\
\text { Tbk. . }\end{array}$ & CITA & 0,4 & 0,95 & 0,05 & 0,18 & 0,97 \\
\hline 13. & $\begin{array}{l}\text { Citatah Industri Marmer } \\
\text { Tbk. }\end{array}$ & CTTH & 0,17 & 0,38 & 0,13 & 0,01 & 0,97 \\
\hline 14. & Darma Henwa Tbk. & DEWA & 0,17 & 0,51 & 0,26 & 0,04 & 0,63 \\
\hline 15 . & Delta Dunia Makmur Tbk. & DIOD & 0 & 0,4 & 0,22 & 0,05 & 1,02 \\
\hline
\end{tabular}




\begin{tabular}{clcccccc}
\hline No. & NAMA PERUSAHAAN & KODE & $\begin{array}{c}\text { IDK } \\
(\mathbf{X 1})\end{array}$ & $\begin{array}{c}\text { KPI } \\
(\mathbf{X 2})\end{array}$ & $\begin{array}{c}\text { CSR } \\
(\mathbf{X 3})\end{array}$ & $\begin{array}{c}\text { R)A } \\
(\mathbf{Y 1})\end{array}$ & $\begin{array}{c}\text { TOBIN'SQ } \\
\text { (Y2) }\end{array}$ \\
\hline 16. & Elnusa Tbk. & ELSA & 0,5 & 0,66 & 0,37 & 0,06 & 0,82 \\
17. & Energi Mega Persada Tbk. & ENRG & 0,4 & 0,68 & 0,36 & 0.09 & 0,83 \\
18. & Garda Tujuh Buana Tbk. & GTBO & 0,67 & 0,6 & 0,1 & 0,26 & 0,82 \\
19. & Golden Energy Mines Tbk & GEMS & 0,6 & 0,97 & 0,22 & 0,03 & 4,22 \\
20. & Harum Energy Tbk. & HRUM & 0,5 & 0,7 & 0.21 & 0,4 & 3,32 \\
21. & Indo Tambang Raya & ITMG & 0,5 & 0,65 & 0,28 & 0,37 & 3,58 \\
& Megah Tbk & & & & & & \\
22. & Medco Energi & MEDC & 0,33 & 0,68 & 0,37 & 0,07 & 0,71 \\
Internasional Tbk.. & & & & & & \\
23. & Mitra Investindo Tbk. & MITI & 0,5 & 0,32 & 0,14 & 0,19 & 1,8 \\
24. & Perdana Karya Perkasa & PKPK & 0,33 & 0,79 & 0 & $-0,02$ & 15,55 \\
& Tbk. & PTRO & 0,43 & 0,7 & 0,22 & 0,15 & 0,91 \\
25. & Petrosea Tbk. & KKGI & 0,4 & 0,63 & 0,23 & 0,34 & 0,97 \\
26. & Resource Alam Indonesia & Thk & & & & & \\
27. & Radiant Utama Interinsco & RUIS & 0 & 0,82 & 0,1 & 0,15 & 0,93 \\
& Tbk. & & & & & & \\
28. & Ratu Prabu Energy Tbk. & ARTI & 0,25 & 0,7 & 0,24 & 0,06 & 0,43 \\
29. & SMR Utama Karya Tbk. & SMRU & 0,33 & 0,85 & 0,18 & $-0,16$ & 0,53 \\
30. & Timah (Pesero) Tbk. & TINS & 0,5 & 0,78 & 0,5 & 0,1 & 1,52 \\
31. & Vale Indonesia Tbk. & INCO & 0,4 & 0,79 & 0,29 & 0,05 & 1,3 \\
\hline
\end{tabular}

Sumber : Data diolah penulis

\section{Pengolahan Data}

Pengolahan data dengan menggunakan regresi sederhana untuk mendapatkan koefisien hubungan kausal variabel independen terhadap variabel dependen baik pada jalur pertama maupun jalur kedua. Selengkapnya model Analisis Jalur (Path Analysis) dengan menggunakan program Software SPSS for Windows release 15.0. dapat dilihat pada tabel 2 berikut ini:

Tabel 2. Hasil Path Analysis Dan Signifikansinya

\begin{tabular}{clccc}
\hline No. & \multicolumn{1}{c}{ Hubungan Kausal } & Koefisien & Signifikasi & Keterangan \\
\hline 01 & IDK $==>$ ROA & 0,51 & 0,784 & Signifikan \\
02 & KPI $==>$ ROA & 0,043 & 0,010 & Signifikan \\
03 & CSR $==>$ ROA & 0,24 & 0,54 & Signifikan \\
04 & ROA ==> NPP & 0,04 & 0,79 & Signifikan \\
05 & IDK $==>$ NPP $($ Model 1) & 0,054 & 0,771 & Signifikan \\
06 & KPI $==>$ NPP (Model 2) & 0,14 & 0,461 & Signifikan \\
07 & CSR $==>$ NPP $($ Model 3 $)$ & 0,29 & 0,113 & Signifikan \\
\hline
\end{tabular}

Sumber: Data diolah penulis 


\section{HASIL DAN PEMBAHASAN}

\section{Hasil Penelitian}

\section{Model Analisis Path}

Bedasar nilai-nilai koefisien path yang terdapat pada tabel 2 tersebut di atas dapat disusun tiga model analisis path. Masing-masing model dan analisisnya adalah sebagai berikut:

a. Model 1

Persamaan Jalur I adalah $\mathrm{ROA}=0,51 \mathrm{IDK}+\mathrm{e} 1$

Persamaan Jalur II adalah Tobin's Q=0,54 IDK + 0,04 ROA + E1

Model analisis path yang pertama pada persamaan jalur I menunjukkan koefisien jalur variabel IDK terhadap ROA adalah positif sebesar 0,51 , artinya apabila IDK meningkat satu satuan maka ROA akan meningkat 0,51 satuan.

Model analisis path yang pertama pada persamaan Jalur II menunjukkan koefisien jalur variabel IDK terhadap Tobin's Q adalah positif sebesar 0,54, artimya apabila IDK meningkat satu satuan maka Tobin'sQ naik 0,54 satuan. Sedangkan koefisien jalur ROA terhadap Tobin's Q adalah positif sebesar 0,04, artinya apabila ROA meningkat satu satuan maka Tobin'sQ naik 0,04 satuan.

b. Model 2

Persamaan Jalur I adalah $\mathrm{ROA}=0,043 \mathrm{KPI}+\mathrm{e} 2$

Persamaan Jalur II adalah Tobin's Q = 0,14 KPI + 0,04 ROA + E2

Model analisis path yang kedua pada persamaan jalur I menunjukkan koefisien jalur variabel KPI terhadap ROA adalah positif sebesar 0,043, artinya apabila KPI meningkat satu satuan maka ROA akan meningkat 0,043 satuan.

Model analisis path yang kedua pada persamaan Jalur II menunjukkan koefisien jalur variabel KPI terhadap Tobin's Q adalah positif sebesar 0,14, artimya apabila KPI meningkat satu satuan maka Tobin's Q naik 0,14 satuan. Sedangkan koefisien jalur ROA terhadap Tobin's Q adalah positif sebesar 0,04, artinya apabila ROA meningkat satu satuan maka Tobin's Q naik 0,04 satuan.

c. Model 3

Persamaan Jalur I adalah $\mathrm{ROA}=0,24 \mathrm{CSR}+\mathrm{e} 3$

Persamaan Jalur II adalah NPP $=0,29 \mathrm{CSR}+0,04 \mathrm{ROA}+\mathrm{E} 3$

Model analisis path yang ketiga pada persamaan jalur I menunjukkan koefisien jalur variabel CSR terhadap ROA adalah positif sebesar 0,24, artinya apabila KPI meningkat satu satuan maka ROA akan meningkat 0,24 satuan.

Model analisis path yang ketiga pada persamaan Jalur II menunjukkan koefisien jalur variabel CSR terhadap Tobin'sQ adalah positif sebesar 0,29, artimya apabila CSR meningkat satu satuan maka Tobin'sQ naik 0,29 satuan. Sedangkan koefisien jalur ROA terhadap Tobin'sQ adalah positif sebesar 0,04, artinya apabila ROA meningkat satu satuan maka Tobin'sQ naik 0,04 satuan. 


\section{Pengujian Hipotesis}

a. Pengaruh Langsung

Hasil pengujian hipotesis untuk mengetahui signifikansi pengaruh varibel bebas terhadap variabel terikat dengan melihat besarnya signifikansi hasil. Apabila signifikansi hasil kurang dari 0,05 maka hipotesis terbukti dan apabila lebih besar dari 0,05 maka hipotesis tidak terbukti. Berikut ini nilai signifikansi tiap - tiap pengaruh langsung :

Tabel 3. Hasil Uji Hipotesis Pengaruh Langsung

\begin{tabular}{clccc}
\hline Hipotesis & Hubungan Kausal & Koefisien & Signifikasi & Keterangan \\
\hline H-01 & IDK $==>$ ROA & 0,51 & 0,784 & Tidak Signifikan \\
H-02 & KPI $==>$ ROA & 0,043 & 0,010 & Signifikan \\
H-03 & CSR $==>$ ROA & 0,24 & 0,54 & Tidak Signifikan \\
H-04 & ROA $=$ = Tobin'sQ & 0,04 & 0,79 & Tidak Signifikan \\
\hline
\end{tabular}

Sumber: Hasil SPSS for Windows release 15.0.

Berdasar nilai signifikansi pada tabel hasil uji hipotesis pengaruh langsung di Tabel 3 tersebut di atas dapat diketahui bahwa hanya hipotesis H-2 : KPI berpengaruh signifikan terhadap ROA karena nilai signifikansinya 0,01 atau lebih kecil dari 0,05, sedangkan ketiga hipotesis yang lainnya tidak signifikan. Jadi hipotesis penelitian ini yang terbukti kebenarannya adalah hipotesis kedua : Kepemilikan Institusional sebagai proksi GCG terbukti berpengaruh terhadap Kinerja Keuangan (ROA).

b. Pengaruh tidak langsung

Pengujian hipotesis pada analisis path untuk mengetahui hubungan tidak langsung variabel IDK, KPI dan CSR terhadap Tobin's Q dengan ROA sebagai variabel intervening dilakukan dengan membandingkan besarnya koefisien pengaruh langsung dan tidak langsungnya. Koefisien pengaruh langsung variabel IDK, KPI dan CSR terhadap Tobin's Q dapat diketahui dari tabel 3, sedangkan koefisien pengaruh tidak langsung dapat dihitung dengan melakukan perkalian koefisien jalur pertama dan jalur lanjutannya.

Berikut ini adalah tabel yang menunjukkan uji hipotesis untuk pengaruh tidak langsung:

Tabel 4. Hasil Uji Hipotesis Pengaruh Tidak Langsung

\begin{tabular}{clccc}
\hline Hipotesis & Hubungan Kausal & Perhitungan & Koefisien & $\begin{array}{c}\text { Keterangan yang } \\
\text { Lebih Baik }\end{array}$ \\
\hline \multirow{3}{*}{ H-05 } & Model 1 : & & & \\
& IDK ==> Tobin's Q & & 0,054 & Langsung \\
& IDK ==> ROA ==> & $0,51 \times 0,04$ & 0,20 & \\
& Tobin's Q & & & \\
& Model 2: & & &
\end{tabular}




\begin{tabular}{clccc}
\hline Hipotesis & Hubungan Kausal & Perhitungan & Koefisien & $\begin{array}{c}\text { Keterangan yang } \\
\text { Lebih Baik }\end{array}$ \\
\hline H-06 & KPI ==> Tobin's Q & & 0,14 & Langsung \\
& KPI ==> ROA ==> & $0,043 \times 0,04$ & 0,002 & \\
& Tobin's Q & & & \\
& Model 3: & & 0,29 & Langsung \\
H-07 & CSR ==> Tobin's Q & & \\
& CSR ==> ROA ==> & $0,24 \times 0,04$ & 0,10 & \\
& Tobin's Q & & & \\
\hline
\end{tabular}

Sumber: Hasil SPSS for Windows release 15.0.

Berdasar tabel perbandingan besarnya koefisien antara pengaruh langsung dan tak langsung antara variabel IDK, KPI dan CSR terhadap Tobin's Q diketahui bahwa keseluruhan lebih besar koefisien pengaruh langsungnya. Hal ini dikarenakan koefisien pengaruh ROA terhadap Tobin's Q sangat kecil yaitu 0,04 saja, sehingga hasil perkalian koefisien jalur pertama dengan selanjutnya menghasilkan koefisien yang semakin kecil. Dari hal tersebut di atas menunjukkan bahwa ROA terbukti tidak bisa digunakan sebagai variabel intervening pada penelitian ini.

\section{Pembahasan}

Pengaruh Langsung

(i) Pengaruh Good Corporate Governance terhadap Kinerja Keuangan (ROA)

Pengaruh GCG terhadap Kinerja Keuangan dengan variabel bebas yang diproksi dengan Independensi Dewan Komisaris dan Kepemilikan Institusional dapat dijelaskan dalam paragraf berikut ini:

Pertama pengaruh langsung IDK terhadap ROA menujukkan koefisien regresi 0,51 dan nilai signifikansi 0,784 . Tingkat signifikansi lebih dari 0,05 , artinya IDK tidak berpengaruh terhadap ROA. Independensi Dewan Komisaris merupakan cerminan perwakilan pemilik yang berhak melakukan pengawasan terhadap jalannya perusahaan dan berhak memberikan nasehat kepada dewan direksi. Dewan komisaris ikut bertanggungjawab dalam keberhasilan dan kepalilitan perusahaan.

Dewan komisaris Independen terdiri dari para profesional dari auditor independen yang dalam penelitian ini ditunjukkan dengan prosentase jumlah komisaris independen. Dilihat dari tidak adanya pengaruh IDK terhadap ROA ini kemungkinan adalah karena pelaksanaan fungsi tidak terkait dengan jumlah komisaris independen, melainkan dari aktivitasnya, misalkan sering tidaknya rapat yang dilakukan dewan komisaris..Dari rapat bisa dihasilkan evaluasi dan saran untuk aktivitas perusahaan periode selanjutnya.

Kedua, pengaruh langsung Kepemilikan Institusional (KPI) terhadap ROA menujukkan koefisien regresi 0,043 dan nilai signifikansi 0,010. Tingkat signifikasi kurang dari 0,05 artinya KPI berpengaruh positif dan signifikan.. KPI ini meupakan proposi lembar saham yang dimiliki suatu organisasi atau institusi. Institusi adalah sebuah entitas yang merupakan sebuah sistem. Sebagai bagian dari pemilik mereka 
berhak memilih dewan direksi dan memiliki hak suara pada rapat pemegang saham, bisa memegang peranan dalam pengambilan keputusan strategis. Oleh karena itu sangat logis bila berpengaruh terhadap pengembalian investasi dalam aset perusahaan.

Hasil penelitian ini tidak bersesuaian dengan hasil penelitian Huang (2011) bahkan berbalikan untuk kedua elemen GCG tersebut, karena penelitian Huang menghasilkan pengaruh IDK signifikan dan positif terhadap ROA, sedangkan KPI tidak berpengaruh terhadap ROA.

(ii) Pengaruh Corporate Social Responsibility (CSR) terhadap Kinerja Keuangan (ROA)

Pengaruh langsung CSR terhadap ROA menujukkan koefisien regresi 0,24 dan nilai signifikansi 0,54. Tingkat signifikansi yang lebih dari 0,05, artinya CSR tidak berpengaruh terhadap ROA. Dalam landasan teori disebutkan ada tiga tipe CSR yaitu Charity, pembinaan usaha kecil secara parsial dan CSR yang produktif yang bisa meningkatkan kesejahteraan masyarakat dan memberi manfaat efisiensi perusahaan yaitu kemitraan yang berkelanjutan.

Dengan tidak berpengaruhnya CSR terhadap ROA kemungkinan CSR yang telah dilaksanakan perusahaan pertambangan belum sampai pada tingkatan CSR yang produktif, tetapi kemungkinan masih pada tingkatan yang kedua atau bahkan mungkin yang pertama. Peneliti belum menemukan penelitian sebelumnya yang menguji hubungan kausal CSR terhadap kinerja keuangann ROA.

(iii) Pengaruh Kinerja Keuangan (ROA) terhadap Nilai Prusahaan (Tobin's Q)

Pengaruh langsung ROA terhadap Tobin's Q menunjukkan koefisien regresi 0,04 dengan tingkat signifikansi sebesar 0,79. Tingkat signifikansi yang lebih dari 0,05, artinya ROA tidak berpengaruh terhadap Tobin's Q. Pengukuran nilai perusahaan dengan Tobin's Q memasukkan nilai pasar saham dan tidak berpengaruhnya ROA terhadap Tobin's Q ini kemungkinan karena informasi tentang ROA tidak direspon investor.

Hasil penelitian ini tidak bersesuaian dengan penelitian Ratih (2011) yang sebelumnya. Kemungkinan penyebabnya adalah perbedaan obyek penelitian dan mungkin karena kurang panjangnya masa penelitian.

b. Pengaruh Tidak Langsung

Dalam penelitian ini tidak ada satupun pengaruh tidak langsung dari ketiga variabel bebas IDK, KPI maupun CSR, sebagaimana tampak pada Tabel 4. di atas. Tabel tersebut menunjukkan bahwa nilai koefisien regresi pengaruh langsung kesemuanya lebih besar dibanding koefisien regresi pengaruh tidak langsungnya. Penyebabnya adalah karena sangat kecilnya koefisien regresi ROA terhadap Tobin's Q.

Berdasar Tabel 4. tersebut peneliti tidak bisa mendapat pembuktian bahwa ROA layak menjadi variabel intervening terhadap hubungan tidak langsung antara IDK, KPI dan CSR terhadap Tobin's Q. Hasil penelitian ini bertentangan dengan hasil penelitian Ratih (2011) sendiri, dimana ROA layak menjadi variabel intervening pada 
pengaruh tidak langsung GCG terhadap Nilai Perusahaan (Tobin's Q). Kemungkinan penyebabnya adalah karena perbedaan obyek penelitian.

\section{SIMPULAN DAN SARAN}

\section{Kesimpulan}

Berdasar pembahasan hasil penelitian yang telah dilakukan dapatlah dibuat beberapa kesimpulan berikut ini:

1. Pada pengujian hipotesis dengan regresi untuk mengetahui pengaruh langsung variabel Good Corporate Governance terhadap Kinerja Keuangan (ROA) diperoleh hasil bahwa hanya unsur KPI yang terbukti berpengaruh terhadap Kinerja Keuangan (ROA) sedangkan unsur IDK tidak ternukti berpengaruh terhadap Kinerja Keuangan (ROA).

2. Pada pengujian dengan regresi untuk mengetahui pengaruh langsung variabel CSR terhadap Kinerja Keuangan (ROA) diperoleh hasil bahwa CSR tidak terbukti berpengaruh terhadap Kinerja Keuangan (ROA.)

3. Pada pengujian hipotesis dengan regresi untuk mengetahui pengaruh langsung Kinerja Keuangan (ROA) terhadap Nilai Perusahaan (Tobin's Q) diperoleh hasil bahwa ROA tidak terbukti berpengaruh terhadap Tobin's Q.

4. Pada pengujian hipotesis dengan cara membandingkan koefisien pengaruh langsung dan hasil perkalian koefisien jalur satu dengan jalur selanjutnya melalui variabel intervening diperoleh hasil tidak satupun model pengaruh tidak langsung dari GCG dan CSR terhadap Nilai Perusahaan yang terbukti kebenarannya.

\section{Saran}

1. Kepada semua perusahaan pertambangan hendaknya tetap memperbaiki sistem GCG dan CSR tidak hanya menyangkut sistem konseptualnya melainkan juga aplikasi yang lebih sempurna dan berkesinambungan. Sebab GCG yang didukung seluruh organ perusahaan akan mampu mewujudkan efisiensi yang tentunya dalam jangka panjang bisa meningkatkan ROA, sementara CSR hendaknya ditingkatkan lagi aplikasinya sampai tercapai CSR yang berefek produktif baik untuk masyarakat maupun bagi perusahaan. Perusahaan hendaknya juga tetap percaya bila ROA bisa berpengaruh terhadap Nilai Perusahaan sebagaiman yang terbukti pada penelitian terdahulu.

2. Bagi Investor, terutama Investor jangka panjang hendaknya selalu memberi masukan kepada Dewan Direksi melalui Dewan Komisaris Independen agar perusahaan mengaplikasikan sistem GCG maupun CSR yang bisa berefek multiplayer baik bagi para stakeholder maupun perusahaan agar bisa meningkatkan ROA maupun Nilai perusahaan pada periode yang akan datang.

3. Bagi peneliti selanjutnya yang ingin meneliti pada bidang yang sama bisa mengganti pengukuran GCG dengan mekanisme GCG dan pengukuran CSR yang lainnya yang lebih menggambarkan aplikasinya. Misalkan GCG diukur dengan banyaknya rapat yang dilakukan, dan CSR dengan meneliti aplikasinya menurut stakeholder. 


\section{DAFTAR PUSTAKA}

Atkinson, Anthony A., R. S. Kaplan, Ella M. M., and S. M. Young, 2007, Management Accounting, Fifth Edition, New Jersey, Pearson - Prentice Hall.

Bapepam, Peraturan No. VIII. G. 2 : Lampiran Keputusan Ketua Bapepam, Nomor: Kep-38/PM/1996, tanggal 17 Januari 1996

Black Bernard S., Woochan Kim, Hasung Jang and Kyung-Suh Park, How Corporate Governance Affects Firm Value: Evidence on Channels from Korea, Journal of Corporate Finance, USA, Social Science Electronic Publishing, Inc, December 1, 2008, 1-48

Bodie Zvi, Alex Kane and Alan J. Marcus, 2005, Investment, Sixth Edition, New York, Mc. Graw Hill

Brigham Eugene F., Michael C. Ehrhardt,2005, Financial Management, Theory and Practice, $11^{\text {th }}$ edition, United State of America, Thomson-South Western,

Denis, Daniel J.and Joanna Legerski, Causal Modeling and the Origins of Path Analysis- Annual Convention of the American Psychological Association, Canada, International Consortium for the Academic Publication Vol. 7 4/19/2007, 1-21,

Donaldson Lex and James H. Davis, Stewardship Theory or Agency Theory: CEO Governance and Shareholder Returns, Australia Journal of Management, The University of New South Wales Vol. 16, 1, June 1991, 49-65

Gibson, Charles A., 1999, Financial Reporting Analysis - Using Financial Accounting Information, Eighth Edition, Canada, South - Western College Publishing

Hair Jr, Joseph F, William C. Black, Barry J. Babin, Ralph E. Anderson, Ronald L. Tathan, 2010, Multivariate Data Analysis, Seventh Edition, United Sate of America, Pearson Education Inc.

Huang Chi Jui, Corporate Governance, Corporate Social Responsiblity and Corporate Performance ( Taiwan Electronic Companies ), Proquest. Umi.com, Nov.2010, Vol 16, $641-656$

Idx, Laporan Tahunan Perusahaan Pertambangan yang Go Public 2012

Iskandar and Chamlou, 2000, Corporate Governance-A Framework For Implementation, Washington DC. USA, The World Bank.

Jensen, Michael C., and William H. Meckling. Theory of the Firm, Managerial Behavior, Agency Costs, and Ownership Structure. Journal of Financial Economics 3 October 1976, 305-360.

Kaihatu Thomas S., Good Corporate Governance dan Penerapannya di Indonesia Jurnal Marketing dan Kewirausahaan, Universitas Kristen Petra, Surabaya Vol. 8 No. 1, Maret 2006, 1-9

Levy, Paul S. and Stanley Lemeshaw, 1999, Sampling of Populations - Methods and Applications, Third Edition, USA, John Wiley \& Sons.

Maher, Maria and Thomas Anderson, Corporate Governance: Effects on Firm Performance Co-operations and Development, Social Science Research 
Network (SSRN)- Social Science Electronic Publishing, Inc., Sept, 22.2000, $1-41$.

Mokhtari, Zobeidah dan Khosro Faghani, 2013, Relationship of Institutional Ownership with Firm Value and Earning Quality : Evidence from Tebran Stock Exchange, International Journal of Economy, Management and Social Sciences., Juli 2013, 495-502

Mulyono, Sri, 2003, Statistik untuk Ekonomi, Edisi Kedua, Jakarta, Lembaga Penerbit Fakultas Ekonomi Universitas Indonesia

Pranata Yuda, Pengaruh Penerapan Good Corporate Governance terhadap Kinerja Keuangan Perusahaan (Peraih 10 besar CGPI), Jurnal Akuntansi Universitas Gunadarma, 16 Apr 2010, 1-74

RI, 2007, UU No. 25 Undang-undang tentang Penanaman Modal (UU PM)

RI,2007, UU. No. 40 - Undang - undang tentang Perseroan Terbatas.

Vernimmen, Pierre, Pascal Quiry, Maurizio Dallocchio, Yan Ie Fur, and Antonio

Salvi, 2009, Corporate Finance - Theory and Practice, Second Edition, United

Kingdom, John Wiley \& Sons Inc.

http://www.bapepam.go.id/uu,13 April 2011, 18.36 WIB

http://www.bpkp.go.id/GCG, 07April 2011, 21.22 WIB

http://www.Business Dictionary.com (2009), 08 Juni 2011, 09.33 WIB

http://www.csrindonesia.com, 09 Mei 2010, 14.44 WIB

http://www.encyclopedia of business, 16 Mei 2011, 12.34 WIB

http://www.greenpeace.org, 12 Maret 2011, 23.06 WIB

http://www.iicg.org, 21 Mei 2011, 17.51 WIB

http://www.fcgi.or.id, 05 April 2011, 